\title{
T, B, and NKT Cells in Systemic Inflammation in Obstructive Sleep Apnoea
}

\author{
Joanna Domagała-Kulawik, ${ }^{1}$ Iwona Osińska, ${ }^{1}$ Aleksandra Piechuta, ${ }^{1}$ \\ Piotr Bielicki, ${ }^{1}$ and Tomasz Skirecki ${ }^{2}$ \\ ${ }^{1}$ Department of Pneumonology and Allergology, Medical University of Warsaw, Ulica Banacha 1a, 02097 Warsaw, Poland \\ ${ }^{2}$ Laboratory of Flow Cytometry, Medical Centre of Postgraduate Education, Ulica Marymoncka 99, 01813 Warsaw, Poland \\ Correspondence should be addressed to Joanna Domagała-Kulawik; domagalakulawik@gmail.com
}

Received 12 January 2015; Revised 12 May 2015; Accepted 12 May 2015

Academic Editor: Tânia Silvia Fröde

Copyright (C) 2015 Joanna Domagała-Kulawik et al. This is an open access article distributed under the Creative Commons Attribution License, which permits unrestricted use, distribution, and reproduction in any medium, provided the original work is properly cited.

\begin{abstract}
Background. Obstructive sleep apnoea syndrome (OSAS) brings risk of serious complications. The study objective was to assess elements of the cellular immune response in the course of OSAS. Methods. Peripheral blood (PB) lymphocytes: T, B, NK, NKT-like, Th, Tc, and HLA DR+ T cells were evaluated by flow cytometry of 48 OSA patients; the concentration of adiponectin, interleukin $1 \beta$, and TNF $\alpha$ was measured by ELISA method. The OSA complication score was developed and used for statistical analysis. Results. The proportion of B cells and Th/Tc ratio were significantly lower in the BP of OSA patients when compared with control subjects (median 7.9 versus $10.9 \%, 0.9$ versus $1.5, p<0.05$ ). The proportion of Tc, NK, NKT-like, and HLADR positive T cells were elevated in OSA patients when compared with healthy subjects (36.4 versus $26.8,15.5$ versus $8.5,5.7$ versus 3.0 , and 8.4 versus $4.5 \%$, $p<$ 0.05 , resp.) and were more pronounced in patients with metabolic syndrome. The grade of OSA complication score correlated with systemic inflammation markers and the proportion of $\mathrm{B}$ cells. The value of adiponectin/BMI ratio correlated significantly with $\mathrm{SpO}_{2}$ $(r=0.31, p<0.05), \mathrm{CRP}(r=-0.35, p<0.05)$, TNF $\alpha$ concentration $(r=-0.36, p<0.05)$, and proportion of B cells $(r=0.32$, $p<0.05)$. Conclusion. Lymphocytes B, Tc, NK, NKT-like, and adiponectin are involved in systemic immune response in OSA patients possibly predisposing them to cardiovascular and metabolic complications.
\end{abstract}

\section{Introduction}

Obstructive sleep apnoea syndrome (OSAS) is the most frequent clinical form of breathing disorders during sleep in patients who come to the sleep medicine specialist. According to the epidemiological research conducted in Poland, the prevalence of the disease is estimated as $8.7 \%$ in men and $2.5 \%$ in women aged $40-72$ yrs. [1]. The most important risk factors for OSAS are obesity, craniofacial structural abnormalities (curvature of the nasal septum, hyperglossia, structural abnormalities and position of the mandible, overgrown tonsils, and structural abnormalities of the soft palate and the uvula), and a decreased upper airway muscle activity. Breathing disorders during sleep increase the risk of cardiovascular complications and especially risk of arterial hypertension [2, 3]. The most pronounced complication and/or coexisting disorder with OSAS is the metabolic syndrome [3]. The OSAS and related comorbidities are accompanied by systemic inflammation with involvement of well-known inflammatory mediators: C-reactive protein (CRP), coagulation factors, lipids, and carbohydrates [2, 4-6]. The participation of proinflammatory cytokines interleukin $1 \beta$ (IL-1 $\beta$ ) and tumor necrosis factor $\alpha(\mathrm{TNF} \alpha)$ in OSA systemic inflammation was established in lots of studies $[2,4$, $7,8]$. Furthermore a reduced concentration of adiponectin, the cytokine of anti-inflammatory properties, was observed $[4,9,10]$. Up to now, some selective data on the influence of OSA on the alterations of lymphocyte population in systemic circulation exist [11-13]. The aim of our study was to investigate the profile of the main lymphocyte subsets in the peripheral blood of patients with severe OSAS with regard to the indices of systemic inflammation. 


\section{Materials and Methods}

2.1. Subjects and PSG. 48 patients with confirmed OSAS were investigated. The diagnosis of OSAS was established in accordance with the American Academy of Sleep Medicine (AASM) and Polish Respiratory Society recommendations $[14,15]$. All patients underwent a 7-hour polysomnography during which we monitored airflow, chest and abdominal motion, and the oxygen arterial blood saturation. A polysomnography test (PSG) was executed with the help of Alice 4 apparatus from RESPIRONICS (USA). Airflow was measured with the use of a pressure cannula or a threechannel thermistor placed in the front nostrils and the mouth area. Chest and abdominal motion were recorded with the use of two piezoelectric belts (around abdomen and chest). Peripheral capillary oxygen saturation $\left(\mathrm{SpO}_{2}\right)$ was recorded with a pulsoximeter. The electroencephalogram (EEG), electrooculogram (EOG), and electromyogram (EMG) were recorded to determine sleep structure and number of awakenings. During sleep cardiac function was monitored by a one-lead ECG. The Epworth Sleepiness Scale (ESS) was used to assess the daytime sleepiness [16]. The diagnosis of OSAS was made when the AHI value exceeded 5 and over 10 points in the ESS.

2.2. Demographics and Laboratory Tests. The basic clinical data were obtained from all the participants, including age, ethnicity, vital signs, weight and BMI, occupation, and a history of smoking status. The following comorbidities were taken into consideration: hypertension, ischemic heart disease, diabetes, stroke, and chronic obstructive pulmonary disease (COPD). In each patient fasting complete blood count, hemoglobin concentration ( $\mathrm{Hb})$, plasma glucose (FPG), total cholesterol (TC), triglycerides (TG), high density lipoprotein cholesterol (HDL-C), and CRP were analyzed in the Central Laboratory of the University Hospital.

For the analysis of clinical data we divided patients to those with and without obesity as well as with and without metabolic syndrome. The obesity was established by body mass index (BMI) as high as $30 \mathrm{~kg} / \mathrm{m}^{2}$ or higher. The metabolic syndrome was defined according to the International Diabetes Federation (IDF) by obesity and a presence of at least two of four features: low HDL concentration ( $<40 \mathrm{mg} / \mathrm{dL}$ in men and $<50 \mathrm{mg} / \mathrm{dL}$ in women), high triglycerides concentration ( $>150 \mathrm{mg} / \mathrm{dL}$ ), hypertension, or diabetes [17]. In addition we designed the authors' own OSA complication score by adding up the following records: obesity, diabetes, hypertension, ischemic heart disease, stroke, and current smoking history. The distribution of patients number in each group of score from 1 to 6 is presented in Figure 1. The demographic data of the patient group are collected in Table 1 .

The control group consisted of 20 healthy volunteers without any chronic disease, who did not receive any treatment, both sexes ( 12 women, 8 men), in the mean age 46 (30-76 years). $5 \%$ smokers constituted $25 \%$ of this group; the mean BMI was $24.32 \pm 3.01 \mathrm{~kg} / \mathrm{m}^{2}$. The study was approved by the Ethics Committee of the Medical University of Warsaw and all the participants gave informed consent.
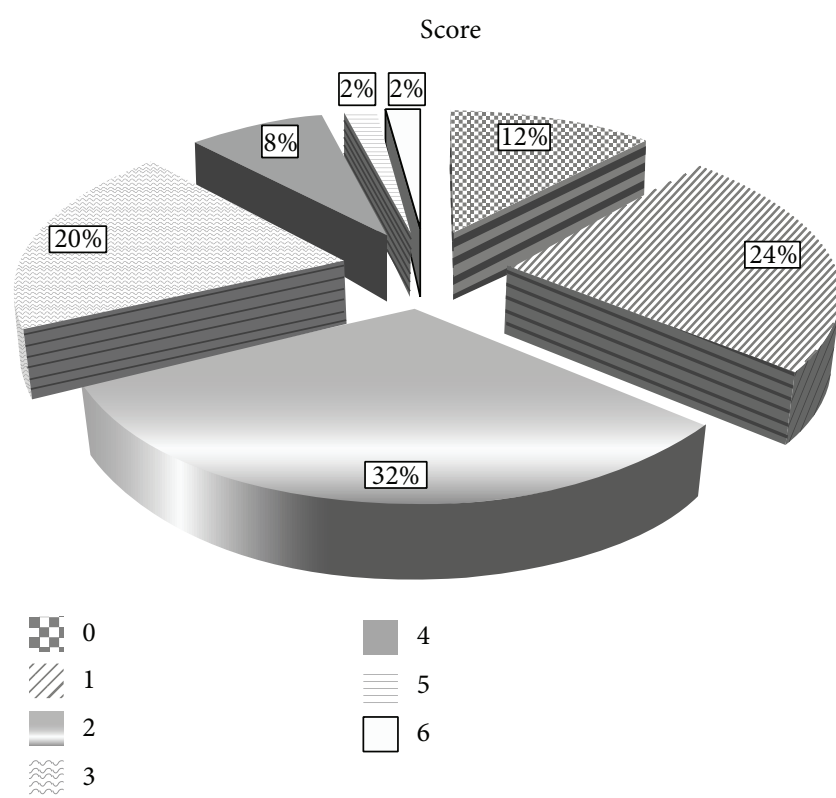

FIGURE 1: OSA complication score and the number of patients distribution in each group. The description of score was included in the main text.

2.3. Flow Cytometry. The venous blood samples were collected before breakfast, early morning. All the analyses were performed right after blood collection. We analysed the proportion of the following lymphocyte subtypes: $\mathrm{T}$ cells, $\mathrm{B}$ cells, T helper (Th) and T cytotoxic cells (Tc), natural killer cells (NK), natural killer T cells (NKT-like), and T cells with HLA-DR expression by Simultest (Becton-Dickinson Immunocytometry Systems, San Jose, California). The following mixtures of antibodies were used: CD3-FITC/CD19PE, CD4-FITC/CD8-PE, CD3-FITC/Anti-HLA-DR-PE, and CD3-FITC/CD16+CD56-PE. In the flow cytometry analysis, first, anti-CD45-FITC and anti-CD14-PE were used for the lymphocyte gate setting at FSC/SSC graph. As a negative isotype control the $\operatorname{IgG}_{1}-\mathrm{FITC} / \mathrm{IgG}_{2 \mathrm{a}}-\mathrm{PE}$ were applied. The analyses were performed using flow cytometry method (FACS Canto II flow cytometer, Becton-Dickinson, San Jose, California), the cells being collected by Diva software (BD). The analysis was performed in the same manner, with the same set of antibodies and in the same conditions in patients and control group. The white blood count was measured in automatic hemocytometer. Total cell number of a particular lymphocyte subpopulation was calculated from WBC and frequency of given population in flow cytometry analysis, next reported as number of cells per $\mu \mathrm{L}$.

2.4. Cytokine Measurements. The serum concentration of adiponectin was measured using Human Total Adiponectin/Acrp30 Immunoassay kit (R\&D System, USA) and ELISA method according to the prescription by the producer. For TNF $\alpha$ and IL-1 $\beta$ concentration measurement we used Human TNF- $\alpha$ and IL- $1 \beta$ Immunoassay, respectively (R\&D System, USA). 
TABLE 1: Demographic data, results of polysomnographic tests and metabolic characteristic of patients with OSA (data expressed as mean $\pm S D$ ).

\begin{tabular}{|c|c|}
\hline Patients number & 48 \\
\hline $\begin{array}{l}\text { Age } \\
\text { (years, mean, [range]) }\end{array}$ & $\begin{array}{c}58.5 \\
{[36-82]} \\
\end{array}$ \\
\hline Sex (female/male) & $15: 33$ \\
\hline $\begin{array}{l}\text { Smokers } \\
(n, \%)\end{array}$ & $\begin{array}{c}n=17 \\
35 \%\end{array}$ \\
\hline Mean pack years & $5.80 \pm 10.54$ \\
\hline $\mathrm{BMI}\left(\mathrm{kg} / \mathrm{m}^{2}\right)$ & $31.68 \pm 6.75$ \\
\hline $\begin{array}{l}\text { Obesity } \\
(\%)\end{array}$ & $\begin{array}{c}n=27 \\
56 \%\end{array}$ \\
\hline $\begin{array}{l}\text { AHI } \\
\left(h^{-1}\right)\end{array}$ & $\begin{array}{c}52.92 \pm 21.02 \\
(8-110)\end{array}$ \\
\hline $\begin{array}{l}\text { sAHI } \\
(\%)\end{array}$ & $\begin{array}{c}N=44 \\
92 \%\end{array}$ \\
\hline ODI & $31.11 \pm 18.51$ \\
\hline $\begin{array}{l}\mathrm{SpO}_{2} \\
\text { Lowest } \\
\text { Mean }\end{array}$ & $\begin{array}{l}76.06 \pm 8.40 \% \\
90.88 \pm 3.20 \% \\
\end{array}$ \\
\hline ESS & $\begin{array}{c}12.23 \pm 5.23 \\
(2-21)\end{array}$ \\
\hline $\begin{array}{l}\text { WBC } \\
\left(\times 10^{3} / \mu \mathrm{L}\right)\end{array}$ & $7.08 \pm 1.78$ \\
\hline $\begin{array}{l}\mathrm{Hb} \\
(\mathrm{g} / \mathrm{L})\end{array}$ & $14.51 \pm 1.34$ \\
\hline $\begin{array}{l}\text { CRP } \\
(\mathrm{mg} / \mathrm{L})\end{array}$ & $4.35 \pm 6.45$ \\
\hline $\begin{array}{l}\text { Total cholesterol } \\
(\mathrm{mg} / \mathrm{dL})\end{array}$ & $196.02 \pm 38.73$ \\
\hline HDL-C (mg/dL) & $50.10 \pm 14.03$ \\
\hline $\begin{array}{l}\text { TG } \\
(\mathrm{mg} / \mathrm{dL})\end{array}$ & $160.4 \pm 124.03$ \\
\hline $\begin{array}{l}\text { Hypertension } \\
(\%)\end{array}$ & $\begin{array}{c}n=34 \\
71 \%\end{array}$ \\
\hline $\begin{array}{l}\text { Diabetes } \\
(\%)\end{array}$ & $\begin{array}{c}N=8 \\
17 \%\end{array}$ \\
\hline $\begin{array}{l}\text { Ischemic heart disease } \\
(\%)\end{array}$ & $\begin{array}{c}n=10 \\
21 \%\end{array}$ \\
\hline $\begin{array}{l}\text { COPD } \\
(\%)\end{array}$ & $\begin{array}{c}N=4 \\
8 \%\end{array}$ \\
\hline Metabolic syndrome & $\begin{array}{c}N=27 \\
56 \%\end{array}$ \\
\hline
\end{tabular}

AHI: apnea/hypopnea index; sAHI: severe OSA; ODI: oxygen desaturation index; ESS: Epworth Sleepiness Scale; $\mathrm{SpO}_{2}$ : peripheral capillary oxygen saturation; HDL-C: high density lipoprotein cholesterol; TG: triglycerides; COPD: chronic obstructive pulmonary disease.

2.5. Statistical Analysis. For data comparison the MannWhitney $U$ test and Kruskal-Wallis test (for data nonnormally distributed) were applied. $p<0.05$ was regarded as significant. The relationships between the data were examined by Spearman's rank correlation coefficient. Correlations with both $r \geq 0.3$ and $p<0.05$ were considered relevant.
TABLE 2: Proportion of lymphocyte subtypes and CD4+ : CD8+ ratio in the peripheral blood of patients with OSA and healthy subjects. Data expressed as median (p25-p75).

\begin{tabular}{lccc}
\hline $\begin{array}{l}\text { Lymphocyte subset } \\
(\%)\end{array}$ & OSA $(n=48)$ & $\begin{array}{c}\text { Healthy subjects } \\
(n=20)\end{array}$ & $p$ \\
\hline $\mathrm{B}$ & 7.9 & 10.9 & $<0.05$ \\
$\mathrm{CD} 19+$ & $5.6-10.7$ & $8.5-13.4$ & \\
\hline $\mathrm{T}$ & 74.4 & 71.7 & $\mathrm{NS}$ \\
$\mathrm{CD} 3+$ & $67.0-80.0$ & $67.8-77.2$ & \\
\hline $\mathrm{Th}$ & 35.5 & 42.4 & 0.005 \\
$\mathrm{CD} 4+$ & $30.9-44.4$ & $39.7-49.7$ & \\
\hline $\mathrm{Tc}$ & 36.4 & 26.8 & 0.02 \\
$\mathrm{CD} 8+$ & $28.1-45.1$ & $23.1-38.7$ & \\
\hline Th $:$ Tc & 0.9 & 1.5 & 0.0003 \\
\hline NK & $0.6-1.5$ & $1.2-1.9$ & \\
CD3-CD16+/CD56+ & $11.5-24.3$ & $6.9-14.6$ & $<0.05$ \\
\hline NKT-like & 5.7 & 3.0 & $<0.05$ \\
CD3+CD16+/CD56+ & $2.8-11.2$ & $1.8-5.8$ & \\
\hline CD3+/HLA DR+ & 8.4 & 4.5 & $<0.05$ \\
\hline
\end{tabular}

\section{Results}

In Table 2 we present the results of flow cytometric analysis of lymphocyte populations in the studied groups and the phenotype of each cell population is shown. The analyses revealed significantly lower proportion and the number of $B$ cells in the $\mathrm{PB}$ of patients with OSAS when compared with control subjects, so were the proportion and a number of Th cells. The Th/Tc ratio was significantly lower in patients than in healthy subjects (median value 0.9 versus $1.5, p=0.003$ ). The proportions and the numbers of Tc, NK, NKT-like, and HLA-DR positive T cells were elevated in OSA patients when compared with healthy subjects: the values and statistical significances are presented in Table 2 . These differences were pronounced in obese patients and in patients with metabolic syndrome (Table 3 ).

The median serum concentration of adiponectin was significantly reduced in OSA patients when compared with healthy subjects $(p<0.05)$ and was lowest in obese OSA patients (Figure 2). Similarly, the index, adiponectin to body mass index (A/BMI), differed significantly between patients with OSA and healthy subjects: median value $0.30(0.19-0.44)$ versus 0.62 (0.41-0.99), respectively, $p=0.0006$. The median $\mathrm{A} / \mathrm{BMI}$ index was lowest in obese OSA patients and was 0.26 (0.17-0.36). It was also decreased in nonobese OSA patients and differed when compared with healthy subjects: median value $0.42(0.27-0.30)$ versus $0.62(0.41-0.99)$, respectively, $p=0.08$.

The median serum concentration of IL-1 $\beta$ was $0.30 \mathrm{pg} / \mathrm{mL}(0.02-0.49)$ and the concentration of $\mathrm{TNF} \alpha$ was $0.90 \mathrm{pg} / \mathrm{mL}(0.57-1.28)$ in the OSA group. Levels of these cytokines did not differ between patients and healthy control subjects. The median concentration of IL- $1 \beta$ and TNF $\alpha$ in patients with metabolic syndrome was elevated when compared with patients without metabolic alterations. 
TABLE 3: Presentation of significant differences of OSAS indices, inflammatory mediators, and selected lymphocyte subpopulations between patients in relation to obesity and metabolic syndrome.

\begin{tabular}{|c|c|c|c|c|c|c|c|}
\hline & & $\begin{array}{l}\text { Obesity } \\
(n=27)\end{array}$ & $\begin{array}{c}\text { Nonobese } \\
(n=21)\end{array}$ & $p$ & $\begin{array}{c}\text { MS } \\
(n=26)\end{array}$ & $\begin{array}{l}\text { Without MS } \\
\quad(n=22)\end{array}$ & $p$ \\
\hline AHI & $\mathrm{h}^{-1}$ & $\begin{array}{c}62.7 \\
39.4-71.6\end{array}$ & $\begin{array}{c}42.4 \\
34.0-51.3\end{array}$ & 0.002 & $\begin{array}{c}46 \\
39-72\end{array}$ & $\begin{array}{c}46 \\
34-63\end{array}$ & NS \\
\hline $\mathrm{SpO}_{2} \min$ & $\%$ & $\begin{array}{c}74.0 \\
67.0-79.0\end{array}$ & $\begin{array}{c}81.0 \\
78.5-85.5\end{array}$ & 0.0002 & $\begin{array}{c}75 \\
68-80\end{array}$ & $\begin{array}{c}80 \\
77-82\end{array}$ & 0.038 \\
\hline CRP & $\mathrm{mg} / \mathrm{dL}$ & $\begin{array}{c}3.6 \\
1.4-7.1 \\
\end{array}$ & $\begin{array}{c}1.0 \\
0.6-2.2 \\
\end{array}$ & 0.002 & $\begin{array}{c}3.6 \\
1.6-5.5\end{array}$ & $\begin{array}{c}1 \\
0.6-2.1\end{array}$ & 0.002 \\
\hline WBC & $\times 10^{3} / \mu \mathrm{L}$ & $\begin{array}{c}7.4 \\
6.0-9.1\end{array}$ & $\begin{array}{c}6.5 \\
5.6-7.2\end{array}$ & 0.04 & $\begin{array}{c}6.9 \\
6-8.9\end{array}$ & $\begin{array}{c}6.7 \\
5.3-7.4\end{array}$ & NS \\
\hline Lymphocytes B & $\%$ & $\begin{array}{c}6.5 \\
5.4-8.5\end{array}$ & $\begin{array}{c}10.5 \\
6.4-12.4\end{array}$ & 0.005 & $\begin{array}{c}7.0 \\
5.4-10\end{array}$ & $\begin{array}{c}9.6 \\
6.7-12.4\end{array}$ & NS \\
\hline NK cells & $n / \mu \mathrm{L}$ & $\begin{array}{c}333 \\
244-474\end{array}$ & $\begin{array}{c}209 \\
126-294\end{array}$ & 0.006 & $\begin{array}{c}329 \\
209-474\end{array}$ & $\begin{array}{c}258 \\
149-337\end{array}$ & 0.03 \\
\hline NKT-like cells & $n / \mu \mathrm{L}$ & $\begin{array}{c}111 \\
58-195\end{array}$ & $\begin{array}{c}55 \\
32-123\end{array}$ & 0.02 & $\begin{array}{c}103 \\
52-183\end{array}$ & $\begin{array}{c}88 \\
35-179\end{array}$ & NS \\
\hline CD3+/HLA DR+ & $n / \mu \mathrm{L}$ & $\begin{array}{c}149 \\
85-242\end{array}$ & $\begin{array}{c}113 \\
55-158\end{array}$ & 0.03 & $\begin{array}{c}162 \\
81-245\end{array}$ & $\begin{array}{c}113 \\
68-153\end{array}$ & NS \\
\hline
\end{tabular}

AHI: apnea/hypopnea index; $\mathrm{SpO}_{2}$ : peripheral capillary oxygen saturation; WBC: white blood cells; MS: metabolic syndrome.

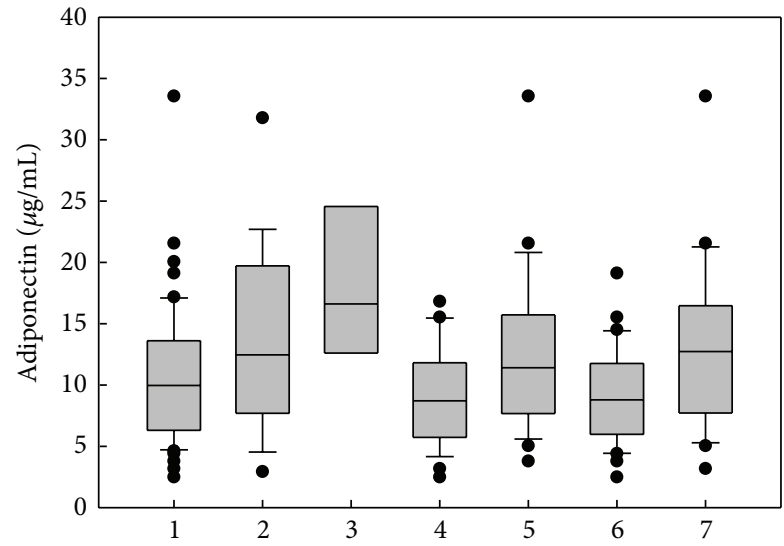

FIGURE 2: Median concentration of adiponectin in peripheral blood of OSA patients and healthy subjects. Plots are the 10th, 25th, 75th, and 90th percentiles as vertical boxes with error bars. 1: all OSA patients; 2: healthy subjects; 3: OSA patients with $\mathrm{BMI}<25$; 4 : obese OSA patients; 5: no obese OSA patients; 6: OSA patients with metabolic syndrome; 7: OSA patients without metabolic syndrome. There was significant difference between groups 3 and 4,6 , and 7 in Kruskal-Wallis test $(p<0.05)$.

It was, respectively, 0.34 versus $0.21 \mathrm{pg} / \mathrm{mL}$ for IL- $1 \beta$ and 0.97 versus $0.82 \mathrm{pg} / \mathrm{mL}$ for TNF $\alpha$ (differences not significant).

When we analysed the influence of coexisting disorders on immune alterations in OSA patients we found a strong relation of obesity and metabolic syndrome therewith. The significant relations of immune parameters with obesity and BMI are presented in Table 3. In patients with coexisting COPD the proportion of $\mathrm{B}$ cells was significantly lower when compared with OSA patients without COPD (3.4 (1.6-5.1) versus $8.5(6.0-11.0), p=0.005)$. No relevant influence of tobacco smoking on investigated immune markers was found.

There was a significant adverse relation of $\mathrm{B}$ cells proportion with CRP concentration $(r=-0.28, p<0.05)$.

The value of A/BMI ratio correlated significantly with $\mathrm{SpO}_{2}(r=0.31)$, with CRP $(r=-0.35)$, and with proportion of B cells $(r=0.32)$ in the whole patients group, while it correlated with $\mathrm{TNF} \alpha$ concentration $(r=-0.36)$ only in the group of obese patients. In nonobese OSA patients group there was significant adverse relation of A/BMI ratio with the proportion of Th cells $(r=-0.44)$. We noticed the tendency of inversed correlation between A/BMI and AHI.

Of the indices of OSA severity we found the relation of ODI with lymphocyte subtypes only in patients burdened with obesity: a positive correlation of ODI with proportion and a number of NKT-like cells was observed $(r=0.40$, $p<0.05)$, presented in Figure 3.

In Table 4 we present the results of the correlation test of OSA severity indices, proportion of lymphocyte subtypes, and the level of inflammatory mediators with BMI and the grade of OSA complication score.

We did not find more relevant correlations between proportions of cell subtypes and the concentrations of adiponectin, IL-1 $\beta$, and TNF $\alpha$ with the demographic data. The mean age in the patients group was significantly higher than in the control group. However, after matching investigated individuals into the groups of comparable age, the differences in the inflammatory indices noted above remained significant.

\section{Discussion}

There are many records supporting the inflammatory nature of OSAS-related comorbidities and the participation of inflammatory cytokines in this process. However, little is 


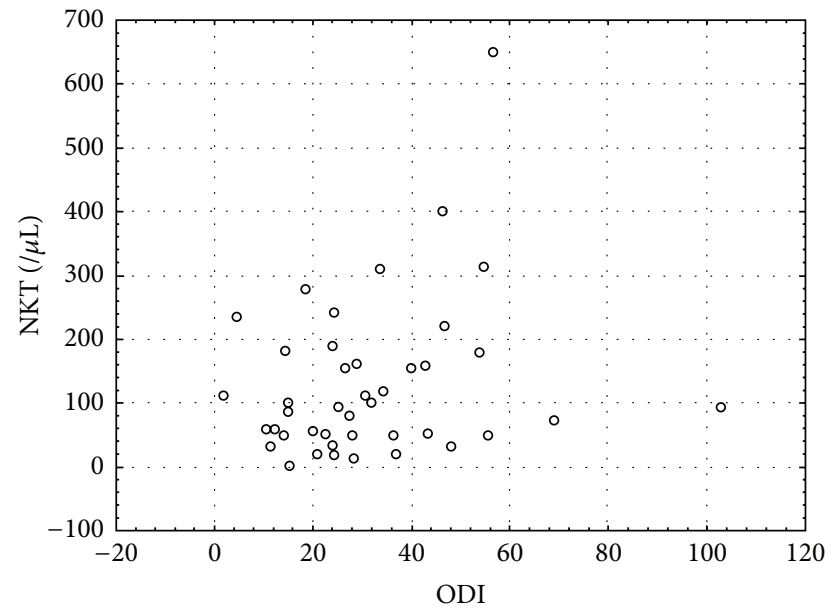

FIGURE 3: Significant correlation between oxygen desaturation index (ODI) and the number of NKT-like cells in the peripheral blood of OSA patients $(r=0.4, p<0.05)$.

TABLE 4: Correlation of the indices of OSA severity, inflammatory markers, and selected lymphocyte subtypes with the index of OSA complication score and BMI (expressed as $r>0.3$, significant $p<$ $0.05)$.

\begin{tabular}{lccc}
\hline & Score & BMI & A/BMI \\
\hline AHI & 0.32 & NS & NS \\
$\mathrm{SpO}_{2}$ min & -0.38 & $\mathrm{NS}$ & 0.32 \\
$\mathrm{SpO}_{2}$ mean & -0.41 & $\mathrm{NS}$ & $\mathrm{NS}$ \\
$\mathrm{CRP}$ & 0.44 & 0.54 & -0.35 \\
Fibrinogen & 0.39 & 0.32 & NS \\
WBC & 0.51 & 0.36 & NS \\
B cells\% & -0.31 & -0.53 & 0.34 \\
NK\% & $\mathrm{NS}$ & 0.35 & NS \\
$\mathrm{CD} 3+/ H L A D R+\%$ & $\mathrm{NS}$ & 0.3 & $\mathrm{NS}$ \\
TNF $\alpha$ & $\mathrm{NS}$ & $\mathrm{NS}$ & -0.36 \\
A/BMI & -0.4 & - & - \\
Adiponectin & $\mathrm{NS}$ & -0.36 & - \\
\hline
\end{tabular}

AHI: apnea/hypopnea index; $\mathrm{SpO}_{2}$ : peripheral capillary oxygen saturation; WBC: white blood cells; BMI: body mass index; A: adiponectin.

known about a character of the cellular immune response in this syndrome. Thus the aim of the present study was the analysis of lymphocyte subtypes in peripheral blood of OSA with regard to the main subpopulations. We observed significant influence of OSAS and OSAS complications on the amounts of circulating inflammatory cells, lymphocytes $\mathrm{B}, \mathrm{Tc}, \mathrm{NK}$, and NKT-like cells, and on the concentration of adiponectin. The studied group consisted of patients with severe OSA. We suspect that the elements of immune alterations observed by us are a consequence of OSA per se.

In our previous studies on local and systemic inflammation in different lung diseases we observed that the changes of lymphocytes profile belong to the most stable and repeatable characteristics of immune response [18-20]. The defined profile of immune system constituents seems to reveal the balance between their activation and suppression and between induction of immune response and the resolution and repair. Usually, patients suffer from OSA for many years before diagnosis and the long-time developing adaptive process should be taken into account. Finally, the severity of the disease varies: in some individuals the hypoxia is deeper while in others it is of slighter degree; thus the level of activation of immune response and anti-inflammatory protection is highly individual. It seems probable that most of immune alterations in the course of OSA are fluent and we detected those changes which are definitely persistent.

The most pronounced disturbances of the cellular response and adiponectin concentration were observed in patients with obesity, metabolic syndrome, and high OSA complication score which is in agreement with other observations $[2,3,6,10]$. We are willing to suspect the following sequence: intermitted hypoxia-inflammation-clinical complications. Chronic intermitted hypoxia acts on the molecular level by activation of the nuclear factor $\kappa \mathrm{B}(\mathrm{NF} \kappa \mathrm{B})$ as well as hypoxia inducible factor 1 (HIF1- $\alpha$ ) and triggers production of inflammatory mediators by oxidative stress. These mediators are also known to affect vascular endothelium $[4,5,21]$.

In the studies of Dyugovskaya et al. on cellular immune response in OSAS, T lymphocytes presented high expression of markers of activation and cytotoxicity, which are AHI dependant. The most affected subtypes were CD8+ cells [12]. The proportion of CD8+ cells bearing CD16 and CD56 NK markers were significantly higher in OSA. It was accompanied by enhanced cytotoxic properties of CD8+ cells. The treatment with nCPAP contributed to normalization of the expression of these markers on CD8 cells. The authors concluded that the presence of CD8+/CD56+/perforin positive cells is involved in inflammatory process leading to cardiovascular complications of OSA [12]. Tan et al. also confirmed high proportion of CD8+ cells and low proportion of CD4+ cells. These changes were AHI dependent in children suffering from OSA [22]. The results of our study: the imbalance of $\mathrm{Th} / \mathrm{Tc}$ with high $\mathrm{Tc}(\mathrm{CD} 8+)$ proportion remains in agreement with what was presented above and with other Dyugovskaya and Lavie results [13]. Interestingly, we observed some alteration of NK cells (the innate lymphoid CD3-negative cells bearing CD56). We also observed an augmentation of NKT cells ( $\mathrm{T}$ cells having both NK and T characteristics, CD3+/CD56+). NKT cells link NK and T cell population bearing similar markers and playing similar immunoregulatory function [23]. There are two members of NKT family in humans: invariant-NKT (iNKT) cells which are CDld stimulated and NKT-like cells which are MHC dependant for antigen presentation [24]. After antigen stimulation NKT cells release Thl, Th2, and Th17 cytokines [24]. The augmentation and increased activity of lung NKTlike cells were described in COPD [25]. In the experimental model of COPD, the iNKT cells responded to cigarette smoke-induced oxidative stress [26]. Oxidative stress is an inherent part of OSAS pathophysiology and the similar NKT activation process could be taking place in OSAS and COPD. The function of the iNKT cells is related to CD1d antigen-presenting molecule recognized lipids [27]. During normal homeostasis there are a high number of 
iNKT cells in the adipose tissue, while in the obesity their proportion is disturbed and these cells possess increased capacity of production of the proinflammatory cytokines [28]. NKT cells and especially iNKT cells were also shown to contribute to the pathophysiology of atherosclerosis, a well-known complication of OSAS [29, 30]. Unfortunately, we investigated NKT cells without precise discrimination to iNKT which needs further investigation in OSAS.

The well-known function of lymphocytes B is humoral immunity but there is growing body of evidence that B cells play also very important role in suppression and regulation of immune response. It is comprehended by release of interleukin 10 (IL-10) and by expression of programmed death ligands 1,2 (PD-L1, PD-L2), Fas-L, and granzyme B which induce $\mathrm{T}$ cells apoptosis [31]. Recently, the functional disturbances of $\mathrm{B}$ cells in adipose tissue were described [32]. We observed for the first time a decreased number of $\mathrm{B}$ cells in the $\mathrm{PB}$ of OSA patients with strong relation to metabolic disorder and obesity. In our study the proportion of B cells was very low in patients with the overlap syndrome OSAS/COPD, but the role of B cells in COPD was highlighted by others [33]. Thus the depletion of circulating B cells seems to promote systemic inflammation in OSAS. Furthermore regulatory $B$ cells present interaction with NKT by CD1d molecule [31]. Our results showing low proportion and number of B cells and augmented population of NKT-like cells in OSA patients are agreeable with the newest data.

We attempted to assess the participation of selected cytokines in the OSA-induced inflammatory process; however, we did not obtain any distinct result. The results of the analysis of cytokines concentration should be interpreted with caution; there are many factors influencing these indices. Serum cytokine level is dynamic and it depends on many conditions: for example, rapid increase of $\mathrm{TNF} \alpha$ was observed just after apnoeic events; the IL- 6 is secreted after effort $[4,34,35]$, although we confirmed the value of the detection of adiponectin concentration in the blood of OSA patients. Adiponectin (known also as adipocyte complementrelated protein of $30 \mathrm{kDa}$, Acrp30) is secreted by adipocytes and regulates metabolic processes. The normal range is $2-10 \mu \mathrm{L} / \mathrm{mL}$ and is stable [36]. In adults the adiponectin concentration is inversely proportional to body mass [21]. The role of adiponectin in regulation of immune system was noted, among others, by antagonizing TNF $\alpha$, IL- 6 secretion and function, induction of IL-10 production, polarization of Th cells to $\mathrm{T}$ regulatory population, and polarization of macrophages from M1 to M2 cells [4, 10, 37]. In our study, the adverse significant correlation of adiponectin concentration with TNF $\alpha$ level and CRP was noted. We confirmed an adverse correlation of adiponectin concentration with body mass index of OSA patients which was previously described in many studies [3]. It was presented that nCPAP treatment influenced adiponectin concentration only in obese patients which suggests that not OSA but obesity affects adiponectin pathway. We found the relation of $\mathrm{A} / \mathrm{BMI}$ with our original OSA complication score: the lower the A/BMI index, the higher the risk of cardiovascular and metabolic complications of OSA. We observed low concentration of this cytokine also in nonobese OSA patients and a correlation of this cytokine concentration with important index of OSA severity, that is, $\mathrm{SpO}_{2}$ min. Al Mutairi et al. also confirmed that the adiponectin level may serve as a marker of OSA severity [9]. Available data are conflicting: in one study no influence of comorbidities on adiponectin level was found [8]; Kosacka et al. in their study on the large group of patients concluded that OSAS does not influence adiponectin level but diabetes was complicated by low level of this cytokine [38]. But, the results of our study emphasised the role of adiponectin in the immunity of OSA per se with possible protective role against development of OSA complications [3,37].

In conclusion, we present for the first time the participation of lymphocytes B, NK, and NKT-like cells in the systemic inflammation in the course of OSAS. These changes are stronger in patients with OSA complications. In addition, the involvement of adiponectin in immune response in OSAS was confirmed. Moreover, the newly developed OSA complication score was proved useful for assessment of common OSA-induced comorbidities and may become a useful tool in further studies.

\section{Conflict of Interests}

The authors declare that there is no conflict of interests regarding the publication of this paper.

\section{Acknowledgment}

This paper was supported by Grant WUM: 1WU/NM 2012.

\section{References}

[1] R. Pływaczewski, M. Bednarek, L. Jonczak, and J. Zieliński, "Sleep-disordered breathing in a middle-aged and older Polish urban population," Journal of Sleep Research, vol. 17, no. 1, pp. 73-81, 2008.

[2] C. Arnaud, M. Dematteis, J.-L. Pepin, J.-P. Baguet, and P. Lévy, "Obstructive sleep apnea, immuno-inflammation, and atherosclerosis," Seminars in Immunopathology, vol. 31, no. 1, pp. 113-125, 2009.

[3] W. T. McNicholas and M. R. Bonsignore, Eds., Sleep Apnea, Europen Respiratory Society Monograph, ERS, 2010.

[4] E. S. Arnardottir, M. Mackiewicz, T. Gislason, K. L. Teff, and A. I. Pack, "Molecular signatures of obstructive sleep apnea in adults: a review and perspective," Sleep, vol. 32 , no. 4, pp. 447470, 2009.

[5] L. Lavie, "Oxidative stress inflammation and endothelial dysfunction in obstructive sleep apnea," Frontiers in Bioscience, vol. 4, no. 4, pp. 1391-1403, 2012.

[6] P. Lavie and L. Lavie, "Cardiovascular morbidity and mortality in obstructive sleep apnea," Current Pharmaceutical Design, vol. 14, no. 32, pp. 3466-3473, 2008.

[7] K. Aihara, T. Oga, Y. Chihara et al., "Analysis of systemic and airway inflammation in obstructive sleep apnea," Sleep and Breathing, vol. 17, no. 2, pp. 597-604, 2013.

[8] D. Testelmans, R. Tamisier, G. Barone-rochette et al., "Profile of circulating cytokines: impact of OSA, obesity and acute cardiovascular events," Cytokine, vol. 62, no. 2, pp. 210-216, 2013.

[9] S. Al Mutairi, O. A. Mojiminiyi, A. Al Alawi, T. Al Rammah, and N. Abdella, "Study of leptin and adiponectin as disease markers 
in subjects with obstructive sleep apnea," Disease Markers, vol. 2014, Article ID 706314, 8 pages, 2014.

[10] B. Gustafson, "Adipose tissue, inflammation and atherosclerosis," Journal of Atherosclerosis and Thrombosis, vol. 17, no. 4, pp. 332-341, 2010.

[11] L. Dyugovskaya, P. Lavie, and L. Lavie, "Phenotypic and functional characterization of blood $\gamma \delta$ T cells in sleep apnea," American Journal of Respiratory and Critical Care Medicine, vol. 168, no. 2, pp. 242-249, 2003.

[12] L. Dyugovskaya, P. Lavie, M. Hirsh, and L. Lavie, "Activated $\mathrm{CD}^{+}$T-lymphocytes in obstructive sleep apnoea," European Respiratory Journal, vol. 25, no. 5, pp. 820-828, 2005.

[13] L. Lavie, L. Dyugovskaya, and A. Polyakov, "Biology of peripheral blood cells in obstructive sleep apnea-the tip of the iceberg," Archives of Physiology and Biochemistry, vol. 114, no. 4, pp. 244-254, 2008.

[14] "Sleep-related breathing disorders in adults: recommendations for syndrome definition and measurement techniques in clinical research. The Report of an American Academy of Sleep Medicine Task Force," Sleep, vol. 22, no. 5, pp. 667-689, 1999.

[15] R. Plywaczewski, A. Brzecka, P. Bielicki et al., "Sleep related breathing disorders in adults-recommendations of Polish Society of Lung Diseases," Pneumonologia i Alergologia Polska, vol. 81, no. 3, pp. 221-258, 2013.

[16] M. W. Johns, "A new method for measuring daytime sleepiness: the Epworth sleepiness scale," Sleep, vol. 14, no. 6, pp. 540-545, 1991.

[17] K. G. M. M. Alberti, P. Zimmet, and J. Shaw, "Metabolic syndrome-a new world-wide definition. A consensus statement from the International Diabetes Federation,' Diabetic Medicine, vol. 23, no. 5, pp. 469-480, 2006.

[18] J. Domagała-Kulawik, G. Hoser, M. Kawalec, A. Doboszyńska, J. Kawiak, and W. Droszcz, "Lymphocyte phenotyping in systemic sclerosis: a flow cytometry analysis of lymphocytes in bronchoalveolar lavage fluid," Analytical and Quantitative Cytology and Histology, vol. 19, no. 3, pp. 264-270, 1997.

[19] J. Domagała-Kulawik, G. Hoser, M. Dabrowska, and R. Chazan, "Increased proportion of Fas positive CD8+ cells in peripheral blood of patients with COPD," Respiratory Medicine, vol. 101, no. 6, pp. 1338-1343, 2007.

[20] G. Hoser, J. Domagała-Kulawik, P. Droszcz, W. Droszcz, and J. Kawiak, "Lymphocyte subsets differences in smokers and nonsmokers with primary lung cancer: a flow cytometry analysis of bronchoalveolar lavage fluid cells," Medical Science Monitor, vol. 9, no. 8, pp. BR310-BR315, 2003.

[21] H. K. Eltzschig and P. Carmeliet, "Hypoxia and inflammation," The New England Journal of Medicine, vol. 364, no. 7, pp. 656665, 2011.

[22] H.-L. Tan, D. Gozal, Y. Wang et al., "Alterations in circulating Tcell lymphocyte populations in children with obstructive sleep apnea," Sleep, vol. 36, no. 6, pp. 913-922, 2013.

[23] K. S. Campbell and J. Hasegawa, "Natural killer cell biology: an update and future directions," Journal of Allergy and Clinical Immunology, vol. 132, no. 3, pp. 536-544, 2013.

[24] M. Rijavec, S. Volarevic, K. Osolnik, M. Kosnik, and P. Korosec, "Natural killer T cells in pulmonary disorders," Respiratory Medicine, vol. 105, supplement 1, pp. S20-S25, 2011.

[25] Y. Tang, X. Li, M. Wang et al., "Increased numbers of NK cells, NKT-like cells, and NK inhibitory receptors in peripheral blood of patients with chronic obstructive pulmonary disease," Clinical and Developmental Immunology, vol. 2013, Article ID 721782, 8 pages, 2013.
[26] M. Pichavant, G. Remy, S. Bekaert et al., "Oxidative stressmediated iNKT-cell activation is involved in COPD pathogenesis," Mucosal Immunology, vol. 7, no. 3, pp. 568-578, 2014.

[27] G. S. Getz, P. A. Vanderlaan, and C. A. Reardon, "Natural killer T cells in lipoprotein metabolism and atherosclerosis," Thrombosis and Haemostasis, vol. 106, no. 5, pp. 814-819, 2011.

[28] L. Lynch, M. Nowak, B. Varghese et al., "Adipose tissue invariant NKT cells protect against diet-induced obesity and metabolic disorder through regulatory cytokine production," Immunity, vol. 37, no. 3, pp. 574-587, 2012.

[29] Y. Andoh, H. Ogura, M. Satoh et al., "Natural killer T cells are required for lipopolysaccharide-mediated enhancement of atherosclerosis in apolipoprotein E-deficient mice," Immunobiology, vol. 218, no. 4, pp. 561-569, 2013.

[30] G. S. Getz, P. A. Vanderlaan, and C. A. Reardon, "Natural killer T cells in lipoprotein metabolism and atherosclerosis," Thrombosis and Haemostasis, vol. 106, no. 5, pp. 814-819, 2011.

[31] M. W. Klinker and S. K. Lundy, "Multiple mechanisms of immune suppression by B lymphocytes," Molecular Medicine, vol. 18, no. 1, pp. 123-137, 2012.

[32] M. A. Exley, L. Hand, D. O'Shea, and L. Lynch, "Interplay between the immune system and adipose tissue in obesity," Journal of Endocrinology, vol. 223, no. 2, pp. R41-R48, 2014.

[33] N. Rovina, A. Koutsoukou, and N. G. Koulouris, "Inflammation and immune response in COPD: where do we stand?" Mediators of Inflammation, vol. 2013, Article ID 413735, 8 pages, 2013.

[34] B. K. Pendersen and A. D. Toft, "Effects of exercise on lymphocytes and cytokines," British Journal of Sports Medicine, vol. 34, no. 4, pp. 246-251, 2000.

[35] B. K. Pedersen and L. Hoffman-Goetz, "Exercise and the immune system: regulation, integration, and adaptation," Physiological Reviews, vol. 80, no. 3, pp. 1055-1081, 2000.

[36] T.-S. Tsao, E. Tomas, H. E. Murrey et al., "Role of disulfide bonds in Acrp30/adiponectin structure and signaling specificity. Different oligomers activate different signal transduction pathways," The Journal of Biological Chemistry, vol. 278, no. 50, pp. 50810-50817, 2003.

[37] C. Wang, "Obesity, inflammation, and lung injury (OILI): the good," Mediators of Inflammation, vol. 2014, Article ID 978463, 15 pages, 2014.

[38] M. Kosacka, A. Korzeniewska, and R. Jankowska, "The evaluation of body composition, adiponectin, C-reactive protein and cholesterol levels in patients with obstructive sleep apnea syndrome," Advances in Clinical and Experimental Medicine, vol. 22, no. 6, pp. 817-824, 2013. 


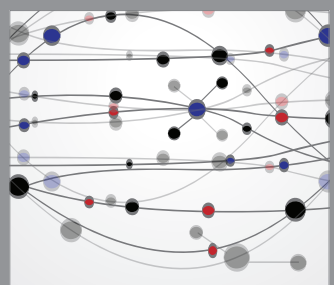

The Scientific World Journal
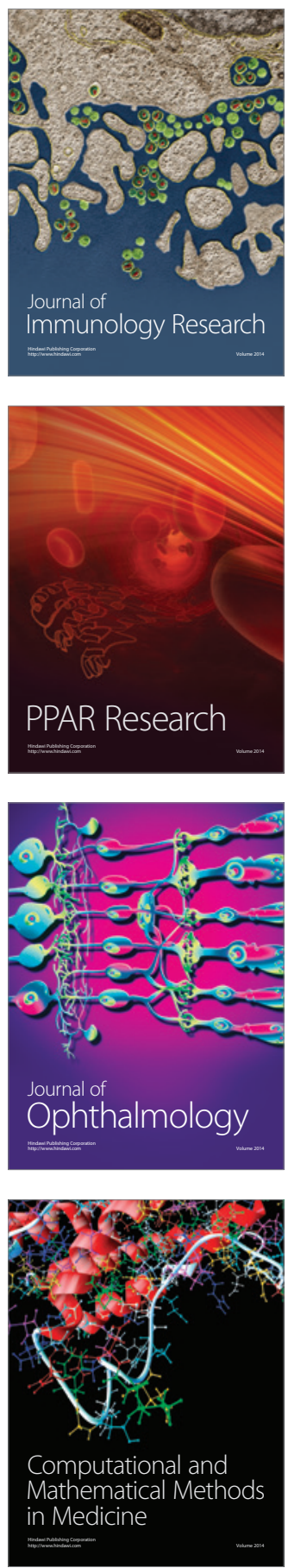

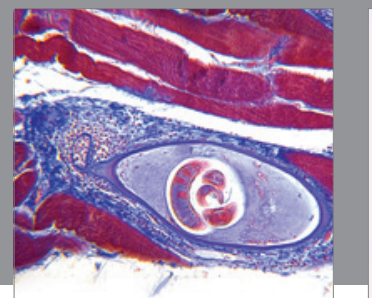

Gastroenterology

Research and Practice
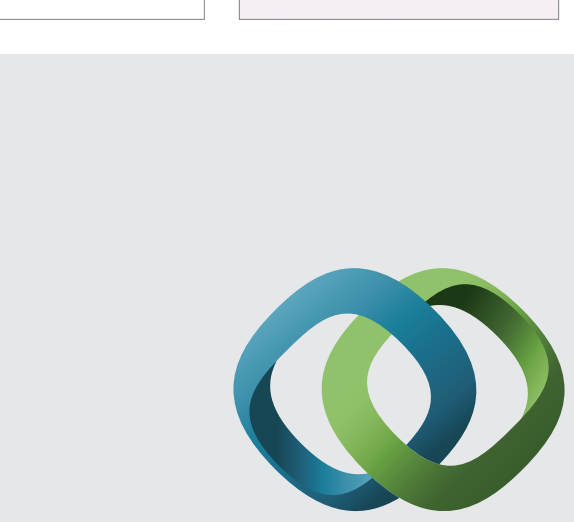

\section{Hindawi}

Submit your manuscripts at

http://www.hindawi.com
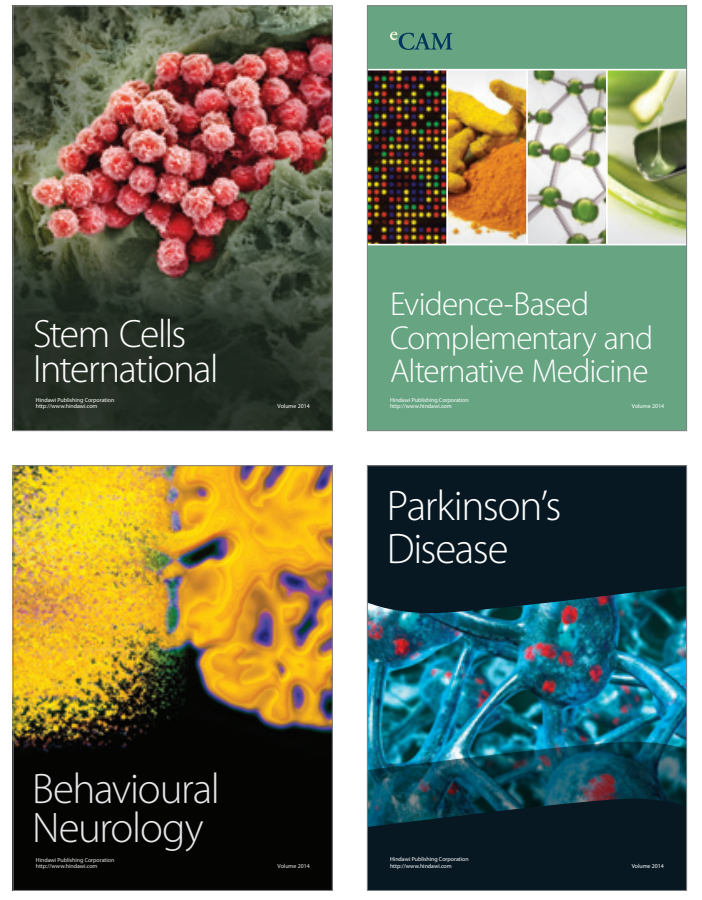
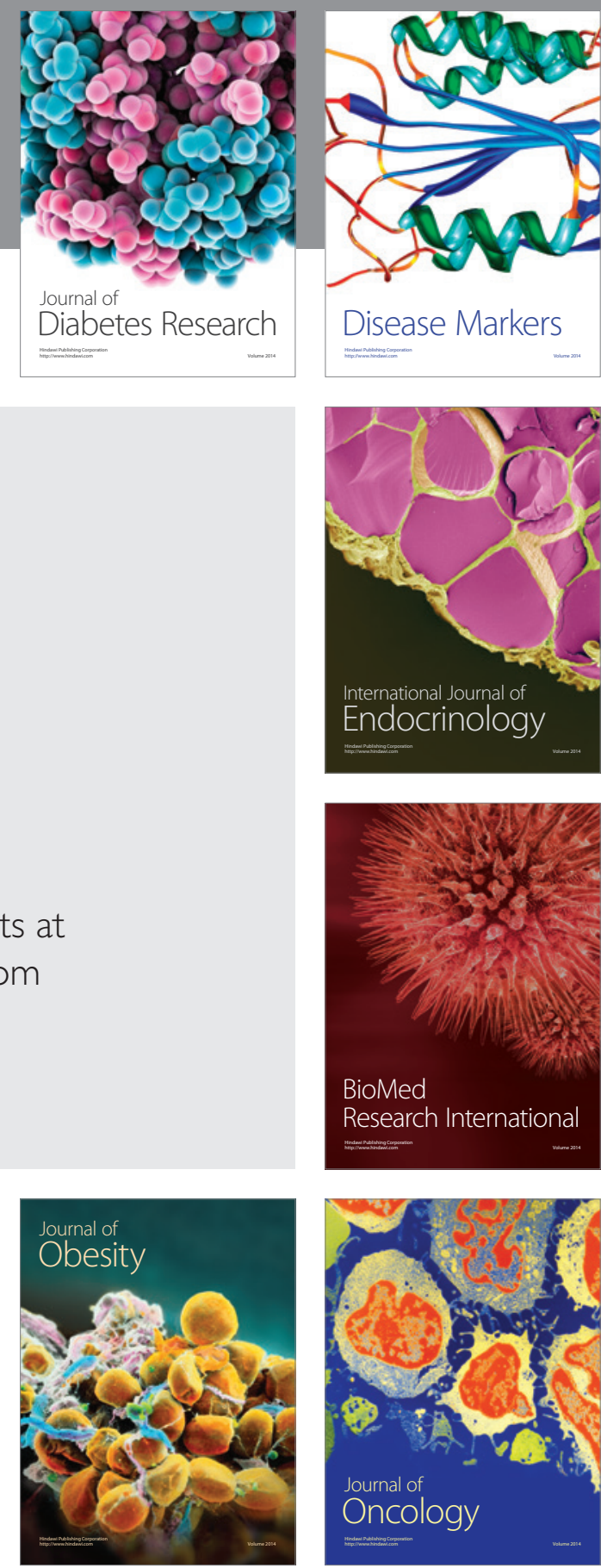

Disease Markers
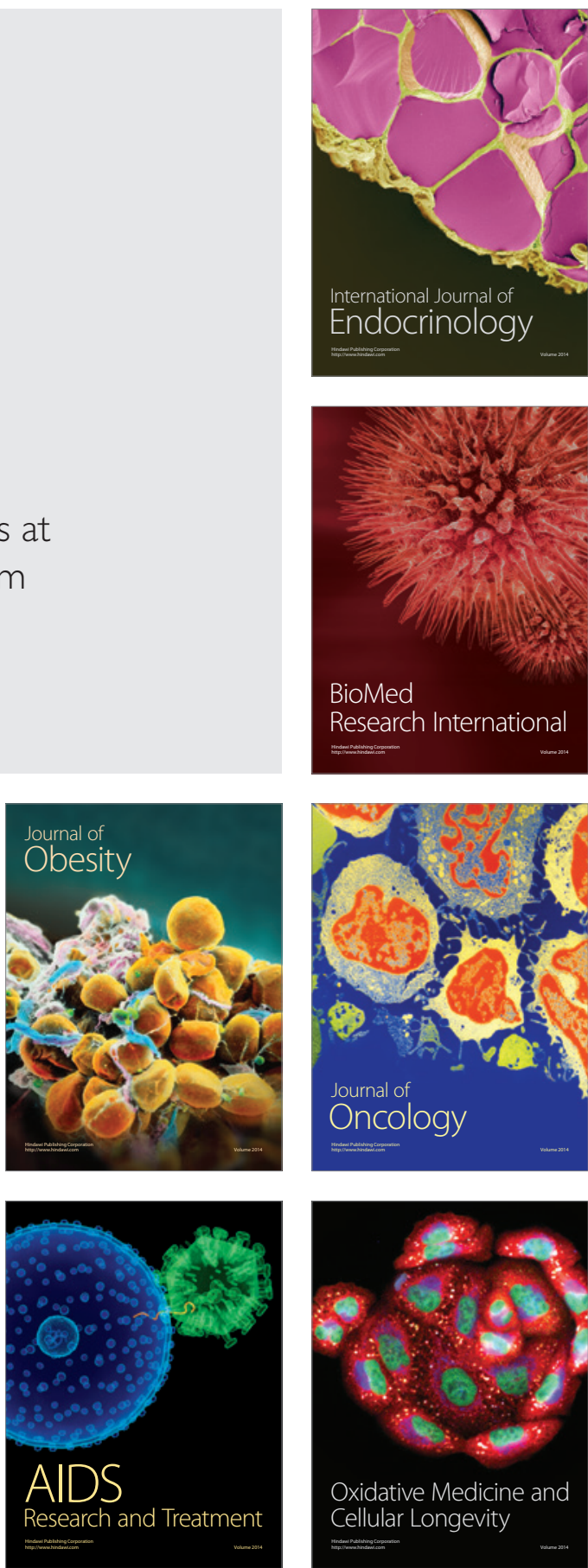